\title{
Can the risk of anal fistula development after perianal abscess drainage be reduced?
}

\author{
Deridun Suat Gokce \\ (iD) Aylin Hande Gokce
}

1. Balıklı Rum Hospital, Department: General Surgery, İstanbul, Turkey. 2. Istanbul Atlas University; Medical Faculty Department: General Surgery, İstanbul, Turkey.

http://dx.doi.org/10.1590/1806-9282.66.8.1082

\begin{abstract}
SUMMARY
OBJECTIVE: Perianal abscesses are frequently seen in clinical practice, and perianal fistulas develop in 30\%-50\% of cases after treatment. This study investigated whether the type of dressing applied after abscess drainage is correlated with fistula development. Prevention of fistula formation would reduce both the loss of work and healthcare costs.

METHODS: The records of patients who underwent drainage of perianal abscesses between January 2015 and January 2018 were retrospectively reviewed. Patients with postoperative dressings changed with washing of the area in the hospital were included as Group 1. Patients with dressings changed at home and the area bathed in 10\% povidone-iodine sitz bath were included as Group 2. The frequency and time of fistula formation, age, sex, cost, and workdays lost in the two groups were compared.
\end{abstract}

RESULTS: Between-group differences in age, sex, body mass index, and type of fistula that developed after months and 1 year of the abscess drainage were not statistically significant ( $p>0.05$ ). During follow-up, fistula development was significantly lower in Group 1 than in Group $2(p<0.001)$. The risk of perianal fistula development was significantly increased in those with a body mass index (BMI) $>30(p=0.004)$.

CONCLUSIONS: After perianal abscess drainage, in-hospital washing and dressing of the abscess area until abscess closure reduced the risk of perianal fistula, lost work time, and cost. The risk of perianal fistula development appeared to increase with BMI. A large, prospective study is needed for confirmation.

KEYWORDS: Abscess. Rectal fistula. Fistula. Drainage.

\section{INTRODUCTION}

Perianal abscesses are frequently seen in clinical practice, and drainage is the standard treatment. Approximately 12,500 cases are surgically treated annually in England, and the annual incidence in Scotland is estimated at 16.1/100.000 population ${ }^{1,2}$. The most generally accepted etiology is cryptoglandular, in which the abscess is caused by inflammation of the anal glands ${ }^{3}$. Perianal abscesses are most common in men in their 30s and $40 s^{4}$. Patients with small superficial abscess can be treated with antibiotics, but the vast majority requires drainage. Untreated perianal abscesses can lead to Fournier's gangrene, which is a life-threatening complication ${ }^{5}$. Perianal abscesses are generally drained surgically in a hospital setting. Abscesses that drain spontaneously usually require additional drainage ${ }^{1}$. Perianal fistulas develop in $30 \%-50 \%$ of patients after drainage and abscess healing. Perianal fistulas may be intersphincteric (simple 
fistula), transsphincteric, suprasphincteric (complex fistula), or extrasphincteric (horseshoe fistula), and generally require surgery ${ }^{6}$. The development of a perianal fistula adds to the overall cost of abscess treatment, additional loss of work time, and the risk of surgical complications. The drainage of perianal abscesses involves preoperative and postoperative antibiotics, which are intended for infection management but have no effect on preventing fistulas ${ }^{7,8}$. Perianal abscesses and fistulas are commonly seen in patients with inflammatory bowel diseases including Crohn's disease, and the treatment of perianal fistulas should be delayed during the active period of the disease ${ }^{9}$.

In this study, fistula development after abscess drainage in patients who sat in hot water during dressing performed outside the hospital and in patients with dressing and abscess area washing in the hospital were compared. Fistula development, the type of fistula, differences in simplicity/complexity, cost, and work time lost in the two groups were compared. The relationship between body mass index (BMI) and fistula development regardless of the dressing change procedure was investigated.

\section{METHODS}

This retrospective cohort study was approved by the local ethics committee (Verdict Number 2019/3510) and was conducted following the ethical guidelines of the Declaration of Helsinki for biomedical studies involving humans. Perianal abscess surgeries performed in our clinic between January 2015 and January 2018 were evaluated. Some surgeons preferred dressing changes with sitz baths at home, others preferred dressing changes in the hospital with washing of the inside of the pouch until closure. The study outcome was fistula development following abscess drainage. The frequencies of fistula development, types of fistula, patient characteristics, cost, and work time lost in each group were determined and compared.

The study included patients aged 18-65 years who visited the clinic for follow-up after a first-time diagnosis and drainage of a perianal abscess. Patients with a history of cancer, a prior perianal fistula and/ or abscess, tuberculosis, recto-vaginal fistula, diabetes mellitus, inflammatory bowel or Crohn's disease, perianal abscess caused by trauma, or internal hemorrhoid surgery were excluded. Pregnant women and patients who did not visit the clinic for follow-up examinations were also excluded. Group 1 included patients with abscess dressing changes done in the hospital. In the first 3 days after drainage, the abscess pouch of Group 1 patients was filled with 3\% hydrogen peroxide followed by $10 \%$ povidone-iodine, and finally with $0.9 \%$ sodium chloride. After that, the site was washed with $0.9 \%$ sodium chloride daily until the abscess pouch was closed (Image 1). Group 2 included patients with dressing changes twice a day after a sitz bath using a $10 \%$ povidone-iodine solution until discharge from the area stopped. Anal fistula development was monitored at 3 and 12 months after abscess drainage (Image 2). Age, sex, the type of the fistula that developed, the time until development, the frequency of development, the cost of treatment, and lost work time in each group were compared. Simple, transsphincteric, and suprasphincteric fistulas were considered complex; extrasphincteric types were considered horseshoe fistulas. Patients were stratified by BMI, as up to < $18.4 \mathrm{~kg} / \mathrm{m}^{2}, 18.5-24.9 \mathrm{~kg} / \mathrm{m}^{2}, 25-29.9 \mathrm{~kg} / \mathrm{m}^{2}$, and $>30$ $\mathrm{kg} / \mathrm{m}^{2}$. Whether fistula development was correlated with BMI regardless of the type of dressing was determined. The cost of hospitalization included the total

IMAGE 1. DRESSING OF PERIANAL ABSCESSES IN THE HOSPITAL SETTING.

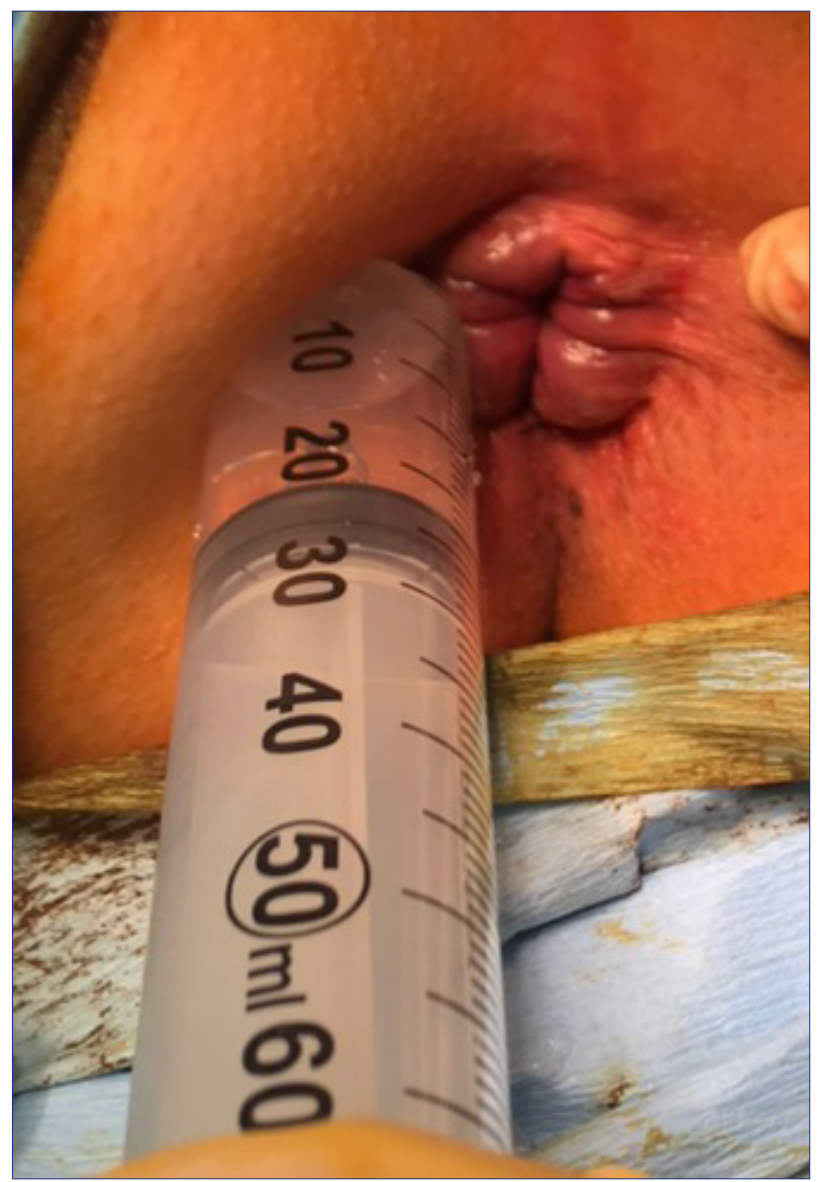


cost of abscess surgery and dressings in United States dollars (USD). Days of home rest and hospital visits for dressings were included; each dressing required after returning to work were calculated as half-days of worktime lost.

\section{Statistical analysis}

Statistical analysis was conducted with SPSS for Windows, version 22.0 IBM Corp., Armonk, NY, USA). The Kolmogorov-Smirnov test was used to determine whether continuous variables were normally distributed. Between-group differences in the values of normally distributed continuous variables were compared using Student's $t$-test. Those that were not normally distributed were compared using the Mann-Whitney $\mathrm{U}$ test. Continuous variables were reported as means and standard deviation. The chi-square test was used

IMAGE 2. DEVELOPMENT OF PERIANAL FISTULAS AFTER PERIANAL ABSCESS DRAINAGE.

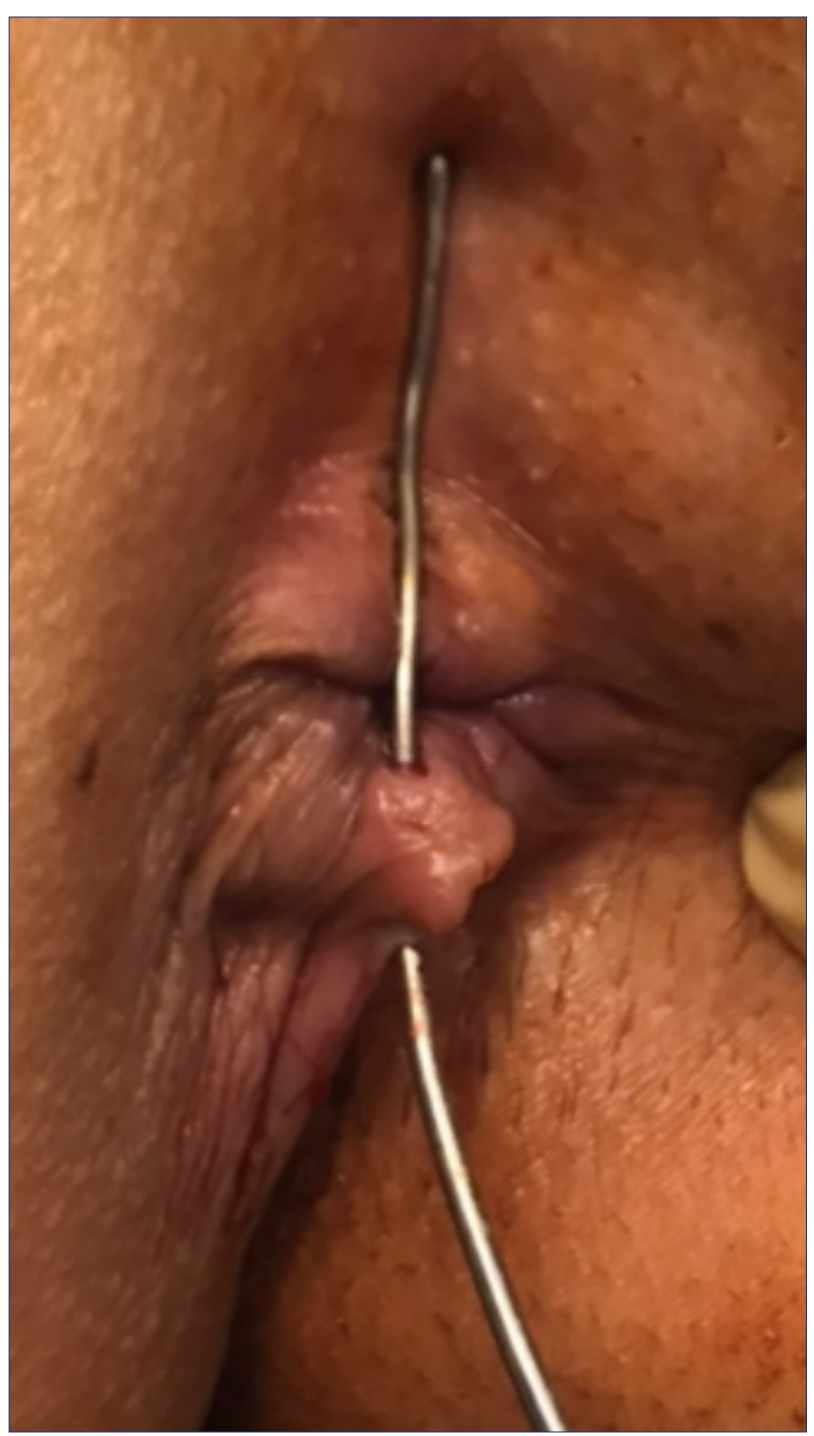

to compare the values of categorical variables. $P$-values $<0.05$ were considered statistically significant.

\section{RESULTS}

\section{Fistula development and fistula type}

Of 340 patients with abscess drainage, the 52 had diabetes mellitus, five a history of abscess drainage, and one an inflammatory bowel disease were excluded. Thirty-eight who did not complete the follow-up visits were not included in the analysis. A total of 119 patients, 79 men and 40 women, were included in Group 1; 125 patients, 90 men and 35 women, were included in Group 2. Differences in sex $(p=0.342)$, mean age (37.6 \pm 12 years versus $39 \pm 12.3$ years), and BMI were not significant $(P=0.778$, Table 1$)$. In Group 1, 14 patients (11.8\%) had anal fistulas at the 3-month follow-up and eight had anal fistulas at the 1-year follow-up (6.7\%), a total of 22 cases (18.5\%). Ninety-seven of the 119 patients with in-hospital dressings (81.5\%) did not develop anal fistulas. Forty patients in group 2 had fistulas at the 3-month follow-up (32\%) and seven had fistulas at the 1-year follow-up (5.6\%), a total of 47 cases (37.6\%). Seventy-eight of the patients with at-home dressings $(62,4 \%)$ did not develop anal fistulas. Fistula development at 3 months was significantly more frequent in Group 2 patients with at-home dressings than it was in Group 1 with in-hospital dressings $(P=0.001)$. In Group 1, 11 fistulas $(50 \%)$ were simple, nine $(41 \%)$ were complex, and two $(9 \%)$ were horseshoe. In Group 2, 26 fistulas (55,3\%) were simple type, $20(42,5 \%)$ were complex, and one $(2,2 \%)$ was horseshoe. The differences in fistula type were not significant $(P=0.415)$.

\section{Workdays lost, cost, and BMI}

A mean of $7.4 \pm 6.8$ work days were lost by Group 1 patients; $6.8 \pm 7.7$ days were lost by Group 2 patients. The difference was not significant $(P=0.499)$. Patients who required anal fistula surgery lost a mean of eight more days of work than those who did not require anal

TABLE 1. BODY MASS INDEX IN GROUPS 1 AND 2.

\begin{tabular}{l|l|l|l} 
Body mass index & $\begin{array}{l}\text { (Group 1) } \\
\text { (n:119) }\end{array}$ & $\begin{array}{l}\text { (Group 2) } \\
\text { (n:125) }\end{array}$ & $\chi^{2}=1.097 ; p=0.778$ \\
\hline Less than 18.4 & $1(\% 0.9)$ & $3(\% 2.4)$ & \\
\hline $18.5-24.9$ & $43(\% 36.1)$ & $47(\% 37.6)$ & \\
\hline $25-29.9$ & $67(\% 56.3)$ & $66(\% 52.8)$ & \\
\hline Over than 30 & $8(\% 6.7)$ & $9(\% 7.2)$ & \\
\hline
\end{tabular}


fistula surgery. The average total cost of the abscess surgery and dressings was USD $626.9 \pm 419.2$ on average for Group 1 patients, and USD $579.2 \pm 462.2$ for Group 2 patients. The difference was not significant $(P=0.843)$. The increased cost attributable to elective surgery for patients who developed an anal fistula was around USD 1100 per case. Anal fistulas developed in one of the four patients (25\%) with BMIs $<18.4 \mathrm{~kg} / \mathrm{m}^{2}$, 19 of $90(21,1 \%)$ with a BMI from $18.5-24.9 \mathrm{~kg} / \mathrm{m}^{2}, 38$ of $133(28,6 \%)$ with a BMI from $25-29.9 \mathrm{~kg} / \mathrm{m}^{2}$, and 11 of $17(64,7 \%)$ with a BMI $>30 \mathrm{~kg} / \mathrm{m}^{2}$. The risk of anal fistula formation was significantly higher in patients with a BMI $>30 \mathrm{~kg} / \mathrm{m}^{2}$ than in those with a BMI of $<$ $30 \mathrm{~kg} / \mathrm{m}^{2}(P=0.004)$.

\section{DISCUSSION}

Anorectal abscesses are cryptoglandular infections including a pus-filled cavity within and deep in the dermis. Perianal abscesses are the most common type ${ }^{1,2}$. The incidence of anorectal abscesses varies among countries and areas. Approximately $29 \%-70 \%$ of patients with anorectal abscesses will develop a fistula, about $33 \%$ of which develop in the months or years after drainage ${ }^{1,6}$. Perianal abscesses most often occur in men in their 30s and $40 \mathrm{~s}^{4}$. The study groups were similar in sex and age, $66.3 \%$ of those in Group 1 and $72 \%$ in Group 2 were men, the mean age was $37.6 \pm 12$ years in Group 1 and $39 \pm 12.3$ in Group 2 . The two groups did not differ in BMI. The majority had a BMI between 18.4 and $29.9 \mathrm{~kg} / \mathrm{m}^{2}$, which is similar to that seen in the general population. A study by Cyzmek et al. ${ }^{10}$ reported that the occurrence of Fournier gangrene in untreated perianal abscess was more frequent in patients with a BMI of 25 or more. Our findings are in line with those of Lu et al. ${ }^{11}$ who reported that anorectal abscess relapse and fistula formation were higher in patients with high BMIs. In this study, perianal fistulas developed significantly more frequently in patients with BMIs $\geq 30$ than in those with lower BMIs $(P=0.004)$. A previous study by Pigot et al. ${ }^{12}$ described the performance of fistula surgery at the same time as drainage of coexistent abscesses but this study excluded patients with both perianal abscess and fistulas.

Few studies have investigated the influence of post-drainage case management on the development of perianal fistulas. Chen et al. ${ }^{8}$ reported that the negative pressure irrigation after abscess drainage decreased fistula development. In this study, perianal fistula development was decreased by washing the abscess area in comparison with the use of a sitz bath $(P=0.001)$. The fistula types that developed in both study groups did not differ, but washing the abscess area in a clinical setting until pouch closure significantly reduced the risk of fistula development compared to the dressings changed at home following a sitz bath. Closure of the fistula pouch by the dressing materials and the mechanical and chemical effects of the medications might account for the difference. Dressing with routine washing of the abscess area may be the preferable method. Published estimates indicate that $30 \%-50 \%$ of patients develop fistulas after drainage of perianal abscesses ${ }^{6}$. In this study, $32 \%$ of the patients in the sitz bath group developed fistulas, which is consistent with previous reports. Only in $18.5 \%$ of patients with that underwent washing of the abscess area before dressing developed fistulas, which was much lower than previously reported. The differences in lost work days and dressing cost in the two groups were not statistically significant, but since Group 1 patients experienced fewer fistulas, there was less need for elective fistula surgery. The cost of USD 1,100 for surgery and eight fewer days of lost work cannot be ignored.

In conclusion, dressing with regular washing of the area until the closure of the abscess pouch reduced the risk of perianal fistula development. Therefore, workforce loss and cost will also decrease. The risk of perianal fistula development was increased in patients with BMIs $>30$, compared to those with lower BMI's.

\section{Author's Contribution}

Planning, data collection, data entry, data analysis, article writing, manuscript analysis and interpretation: Feridun Suat Gokce, Aylin Hande Gokce.

No competing financial interests exist. This research did not receive grants from any funding agency in the public, commercial, or not-for-profit sectors. There are no conflicts of interest present. Ethical approval for this study was obtained from the Ethics Committee (2019/35-10). 


\section{RESUMO}

OBJETIVO: Abscessos perianais são vistos com freqüência na clínica e uma fístula perianal se desenvolve em 30\% a 50\% dos casos após o tratamento. Este estudo investigou se o tipo de curativo aplicado após a drenagem do abscesso está correlacionado com o desenvolvimento da fístula. A prevenção da formação de fístulas reduziria a perda de trabalho e os custos com saúde.

MÉTODOS: Os prontuários de pacientes com drenagem de abscessos perianais entre janeiro de 2015 e janeiro de 2018 foram revisados retrospectivamente. Os pacientes com curativos pós-operatórios trocados com a lavagem da área no hospital foram incluídos no grupo 1. Os pacientes com curativos trocados em casa e a área banhada em $10 \%$ de banho de povidona com iodo povidona-Sitz foram incluídos no grupo 2. A frequência e o tempo de fístula formação, idade, sexo, custo e dias de trabalho perdidos nos dois grupos foram comparados.

RESULTADOS: As diferenças entre os grupos em idade, sexo, índice de massa corporal e o tipo de fístula que se desenvolveu após 3 meses $e 1$ ano após a drenagem do abscesso não foram estatisticamente significantes ( $p>0,05)$. Durante o acompanhamento, o desenvolvimento da fístula foi significativamente menor no grupo 1 do que no grupo $2(p<0,001)$. O risco de desenvolvimento de fístula perianal aumentou significativamente naqueles com índice de massa corporal $(I M C)>30(p=0,004)$.

CONCLUSÕES: Após a drenagem do abscesso perianal, a lavagem hospitalar e o curativo da área do abscesso até o fechamento do abscesso reduziram o risco de fístula perianal, perda de tempo de trabalho e custo. O risco de desenvolvimento de fístula perianal pareceu aumentar com o IMC. Um grande estudo prospectivo é necessário para confirmação.

PALAVRAS-CHAVE: Abscesso. Fístula retal. Fístula. Drenagem.

\section{REFERENCES}

1. Sahnan K, Adegbola SO, Tozer PJ, Watfah J, Phillips RK. Perianal abscess. BMJ. 2017;356:j475.

2. Adamo K, Sandblom G, Brännström F, Strigård K. Prevalence and recurrence rate of perianal abscess: a population-based study, Sweden 1997-2009. Int | Colorectal Dis. 2016;31(3):669-73.

3. Parks AG, Gordon PH, Hardcastle JD. A classification of fistula-in-ano. $\mathrm{Br}$ J Surg. 1976;63(1):1-12.

4. Vogel JD, Johnson EK, Morris AM, Paquette IM, Saclarides TJ, Feingold DL, et al. Clinical practice guideline for the management of anorectal abscess, fistula-in-ano, and rectovaginal fistula. Dis Colon Rectum. 2016;59(12):1117-33.

5. Sözener U, Gedik E, Kessar Aslar A, Ergun H, Halil Elhan A, Memikoğlu O, et al. Does adjuvant antibiotic treatment after drainage of anorectal abscess prevent development of anal fistulas? A randomized, placebo-controlled, double-blind, multicenter study. Dis Colon Rectum. 2011;54(8):923-9.

6. Amato A, Bottini C, De Nardi P, Giamundo P, Lauretta A, Realis Luc A, et al. Evaluation and management of perianal abscess and anal fistula: a consensus statement developed by the Italian Society of Colorectal Surgery (SICCR). Tech Coloproctol. 2015;19(10):595-606.
7. Ommer A, Herold A, Berg E, Fürst A, Post S, Ruppert R, et al. German S3 guidelines: anal abscess and fistula (second revised version). Langenbecks Arch Surg. 2017;402(2):191-201.

8. Chen SQ, Liu WC, Zhang ZZ, Lin LY, Chen SM, Huang GL, et al. Application of closed negative pressure irrigation and suction device in the treatment of high perianal abscess. Zhonghua Wei Chang Wai Ke Za Zhi. 2019;22(4):364-9.

9. Pogacnik JS, Salgado G. Perianal Crohn's disease. Clin Colon Rectal Surg. 2019;32(5):377-85.

10. Czymek R, Hildebrand P, Kleemann M, Roblick U, Hoffmann M, Jungbluth $T$, et al. New insights into the epidemiology and etiology of Fournier's gangrene: a review of 33 patients. Infection. 2009;37(4):306-12.

11. Lu D, Lu L, Cao B, Li Y, Cao Y, Li Z, et al. Relationship between body mass Index and recurrence/anal fistula formation following initial operation for anorectal abscess. Med Sci Monit. 2019;25:7942-50.

12. Pigot F. Treatment of anal fistula and abscess. J Visc Surg. 2015;152(2 Suppl):S23-9. 